\title{
Synthesis, Molecular Docking and Biological Properties of Novel Thiazolo[4,5-b] pyridine Derivatives
}

\author{
Taras I. Chaban, ${ }^{1, \star}$ Yulia E. Matiichuk, ${ }^{1}$ Olga Ya. Shyyka, ${ }^{2}$ Ihor G. Chaban, ${ }^{3}$ \\ Volodymyr V. Ogurtsov, ${ }^{1}$ Ihor A. Nektegayev ${ }^{4}$ and Vasyl S. Matiychuk ${ }^{2}$ \\ ${ }^{1}$ Department of General, Bioinorganic, Physical and Colloidal Chemistry, Danylo Halytsky Lviv National Medical University, \\ 69 Pekarska, Lviv, 79010, Ukraine \\ ${ }^{2}$ Department of Organic Chemistry, Ivan Franko National University of Lviv, 6 Kyryla i Mefodia, Lviv, 79005, Ukraine \\ ${ }^{3}$ Department of Pharmaceutical Chemistry FPGE, Danylo Halytsky Lviv National Medical University, \\ 69 Pekarska, Lviv, 79010, Ukraine \\ ${ }^{4}$ Department of Pharmacology, Danylo Halytsky Lviv National Medical University, 69 Pekarska, Lviv, 79010, Ukraine \\ *Corresponding author: E-mail: chabantaras@ukr.net (Taras I. Chaban) \\ Tel. +38098 942-79-56; Fax. +38 0322 75-77-34
}

Received: 07-24-2019

\begin{abstract}
The synthesis, anti-inflammatory and antioxidant properties of novel 5-hydroxy-7-methyl-3H-thiazolo[4,5- $b]$ pyridin2-one derivatives were discussed. Fused thiazolo[4,5-b]pyridin-2-ones were synthesized and modified at the $\mathrm{N}^{3}, \mathrm{C}^{5}$ and $\mathrm{C}^{6}$ positions of the main core in order to obtain the compounds with a satisfactory pharmacological profile. The synthesized compounds were preselected via molecular docking for further testing of their anti-inflammatory activity in vitro. Evaluation of novel compounds over the carageenin induced rat paw edema revealed strong anti-inflammatory action of some compounds including (thiazolo[4,5-b]pyridin-3(2H)-yl) propanenitrile (5) and thiazolo[4,5-b]pyridin-3(2H)-yl) propanoic acid (6) even exceeding the standard - Ibuprofen. The antioxidant activity of the synthesized compounds was measured in vitro by the method of scavenging effect on 2,2-diphenyl-1-picrylhydrazyl (DPPH) radicals.
\end{abstract}

Keywords: Organic synthesis; thiazolo[4,5-b]pyridin-2-ones; anti-inflammatory activity; antioxidant activity; molecular docking

\section{Introduction}

Inflammation is an essential response of living organisms to the common ailments starting from traumatic disorder or fever associated with infection to major life-threatening diseases like myocardial infarction or brain haemorrhage or infarct. ${ }^{1}$ Literature data survey has revealed that numerous nonsteroidal anti-inflammatory drugs (NSAIDs), which belong to different chemical classes, have been developed to treat inflammatory disorders. During the past few years, the long-term use of NSAIDs has been severely hampered by the emerging of several serious effects such as gastrointestinal ulcers, hepatotoxicity, renal dysfunction, and cardiotoxicity. ${ }^{2}$ Unfortunately all of the proposed medications provoke serious side effects. ${ }^{3}$
In general, NSAIDs exert their pharmacological action by inhibiting the synthesis of prostaglandins (PGs) by non-selectively cyclooxygenases 1 and 2 (COX-1 and COX2), either selective COX-2 blocking. Inhibition of COX-1 is also responsible, in part, for gastrointestinal side effects, which are the most frequent side effects of NSAIDs. ${ }^{4}$ These conditions generate one of the biggest challenges of modern medicinal chemistry for the development of alternative anti-inflammatory drugs with minimal adverse effects. ${ }^{5-7}$

No less challenging is the search for new antioxidants. Different environmental stress factors like pollution, drought, temperature, excessive light intensities, and nutritional limitation can increase the production of reactive oxygen species (ROS) ${ }^{8-9}$ Oxidative stress is a major contributing factor for developing degenerative diseases 
like atherosclerosis, ischemic heart disease, ageing, diabetes mellitus, cancer and others. ${ }^{10}$ Antioxidants can interfere with the oxidation process by reacting with free radicals, and also by acting as reactive species scavenger. ${ }^{11}$ Therefore, various natural well and synthetic antioxidants are used to scavenge free radicals. In this regard, it is important to synthesize new classes of compounds with antioxidant properties.

Fused bicyclic systems with thiazolidine core occupy a prominent place in medicinal chemistry due to their broad spectrum of pharmacological activities. ${ }^{12-14}$ Previously, we have developed convenient and efficient method to form combinatorial libraries of fused azoles such as $[1,2,4]$ triazolo[3,4- $b][1,3,4]$ thiadiazole, ${ }^{15-16}$ pyrazolo $[3,4-d]$ pyridazines, ${ }^{17}[1,2,4]$ triazolo $[3,4-b][1,3,4]$ thiadiazines, ${ }^{18}$ isoindolo[ $[1,2-a]$ isoquinoline,${ }^{19}$ thiopyrano[2,3- $\left.d\right]$ $[1,3]$ thiazoles, ${ }^{20}$ thieno[3,2-c]pyridinone, ${ }^{21}$ triazolo[4,5- $\left.d\right]$ pyridazine, ${ }^{22}$ and thiazolo[4,5-b]pyridines. ${ }^{23}$ In summing up the published scientific data fused thiazolopyridines are characterized by herbicidal, ${ }^{24}$ antioxidant, ${ }^{25-28}$ antimicrobial, ${ }^{29}$ antifungal, ${ }^{30}$ and anti-mitotic ${ }^{31}$ activities. They also show potent inhibitory activities for $\mathrm{A} \beta 42$ fibrillization for Alzheimer's disease treatment. ${ }^{32}$ It was established that thiazolopyridine derivatives exhibit anti-tuberculosis, ${ }^{33}$ anti-inflammatory ${ }^{34-36}$ and significant anticancer ${ }^{37}$ activity, and also act as agonists of H3-histamine receptors. $^{38}$

For the time being, exploration of different chemical modifications avenues of thiazolopyridines to obtain novel active compounds, and thus, the development of a new class of anti-inflammatory drugs with optimal pharmacokinetic properties should be continued.

The present work is devoted to the synthesis of a series of novel $3 \mathrm{H}$-thiazolo[4,5-b]pyridine-2-ones by the structural modification of the core heterocycle in its $\mathrm{N}^{3}, \mathrm{C}^{5}$ and $\mathrm{C}^{6}$ positions for further pharmacological in vivo anti-inflammatory activity assay based on the results obtained via computer simulation - molecular docking and in vitro antioxidant screenings.

\section{Experimental Section}

\section{1. Materials}

All chemicals were of analytical grade and commercially available. All reagents and solvents were used without further purification and drying.

\section{2. Chemistry}

All melting points were determined in an open capillary and are uncorrected. ${ }^{1} \mathrm{H}$ and ${ }^{13} \mathrm{C}$ NMR spectra were recorded on a Varian Mercury $400\left(400 \mathrm{MHz}\right.$ for $\left.{ }^{1} \mathrm{H}\right)$ instrument with TMS or deuterated solvent as an internal reference. Mass spectra were run using Agilent 1100 series LC/MSD, Agilent Technologies Inc. with an API-ES/APCI ionization mode. Satisfactory elemental analyses were obtained for new compounds ( $\mathrm{C} \pm 0.17, \mathrm{H} \pm 0.21, \mathrm{~N} \pm 0.19$ ).

General procedure for the synthesis 6-arylazo-5-hydroxy-7-methyl-3H-thiazolo[4,5-b]pyridin-2-ones $(2,3)$.

Sodium $(0.2 \mathrm{~mol})$ was dissolved in anhydrous methanol $(100 \mathrm{~mL})$. To the obtained solution 4-iminothiazolidin-2-one $(50 \mathrm{mmol})$ and $\alpha$-arylazo-derivative of ethyl acetoacetate $(50 \mathrm{mmol})$ were added at $20^{\circ} \mathrm{C}$. The mixture was left for 7 days with the intermittent stirring. Afterwards, it was acidified with acetic acid to $\mathrm{pH} 5$ and fivefold diluted with water. The precipitate was filtered off, washed with water, and dried at $100-110^{\circ} \mathrm{C}$. The obtained compounds were recrystallized from acetic acid.

\section{4-((5-Hydroxy-7-methyl-2-oxo-2,3-dihydrothiazolo} [4,5-b]pyridin-6-yl)diazenyl) benzene-sulfonic acid (2):

Red solid; yield: $88 \%$; mp $>280{ }^{\circ} \mathrm{C} ;{ }^{1} \mathrm{H}$ NMR $(400$ $\left.\mathrm{MHz}, \mathrm{CDCl}_{3}\right) \delta 2.37\left(\mathrm{~s}, 3 \mathrm{H}, \mathrm{CH}_{3}\right), 7.59(\mathrm{~d}, J=8.1 \mathrm{~Hz}, 2 \mathrm{H}$, $\left.\mathrm{C}_{6} \mathrm{H}_{4}\right), 7.69\left(\mathrm{~d}, J=7.9 \mathrm{~Hz}, 2 \mathrm{H}, \mathrm{C}_{6} \mathrm{H}_{4}\right), 13.30(\mathrm{~s}, 1 \mathrm{H}, \mathrm{OH})$, $14.55(\mathrm{~s}, 1 \mathrm{H}, \mathrm{NH}) ;{ }^{13} \mathrm{C}$ NMR $\left(101 \mathrm{MHz}, \mathrm{CDCl}_{3}\right) \delta 16.88$, $116.35,122.65,125.27,127.08,140.78,141.58,145.48$, 159.99, 166.28, 177.45; ESI-MS: $\mathrm{m} / \mathrm{z} 366[\mathrm{M}+\mathrm{H}]^{+}$; anal. calcd. for $\mathrm{C}_{13} \mathrm{H}_{10} \mathrm{~N}_{4} \mathrm{O}_{5} \mathrm{~S}_{2}: \mathrm{C} 42.62, \mathrm{H} \mathrm{2.75}, \mathrm{N}$ 15.29; found: C 43.01, H 2.68, N 15.35.

5-Hydroxy-7-methyl-6-(naphthalen-2-yldiazenyl)thiazolo[4,5-b]pyridin-2(3H)-one (3):

Red solid; yield: $84 \%$; mp $265{ }^{\circ} \mathrm{C} ;{ }^{1} \mathrm{H}$ NMR (400 $\left.\mathrm{MHz}, \mathrm{CDCl}_{3}\right) \delta 2.45\left(\mathrm{~s}, 3 \mathrm{H}, \mathrm{CH}_{3}\right), 7.67(\mathrm{~d}, J=6.8 \mathrm{~Hz}, 2 \mathrm{H}$, naphthalen), 7.74-7.77 (m, 1H, naphthalen), 7.88-7.90 ( $\mathrm{m}, 1 \mathrm{H}$, naphthalen), 7.98-8.07 ( $\mathrm{m}, 3 \mathrm{H}$, naphthalen), $13.46(\mathrm{~s}, 1 \mathrm{H}, \mathrm{OH}), 15.74(\mathrm{~s}, 1 \mathrm{H}, \mathrm{NH}) ;) ;{ }^{13} \mathrm{C}$ NMR $(101$ $\left.\mathrm{MHz}, \mathrm{CDCl}_{3}\right) \delta 16.90,114.83,115.86,121.34,125.49$, $125.96,127.17,127.80,127.84,129.90,131.46,132.12$, 133.26, 135.20, 136.17, 139.48, 140.50, 160.54; ESI-MS: $\mathrm{m} / \mathrm{z} 336[\mathrm{M}+\mathrm{H}]^{+}$; anal. calcd. for $\mathrm{C}_{17} \mathrm{H}_{12} \mathrm{~N}_{4} \mathrm{O}_{2} \mathrm{~S}: \mathrm{C} 60.70, \mathrm{H}$ 3.60, N 16.66; found: C 60.44, H 3.63, N 16.58.

\section{5-Hydroxy-7-methyl-3-phenylthiazolo[4,5-b]pyridin-2} (3H)-one (4):

Sodium (109 mmol) was dissolved in anhydrous methanol $(150 \mathrm{~mL})$. To the obtained solution 3-phenyl-4-iminothiazolidin-2-one $(50 \mathrm{mmol})$ and ethyl acetoacetate $(8,5 \mathrm{~mL})$ were added at $20^{\circ} \mathrm{C}$. The mixture was left for 5 days with the intermittent stirring. Afterwards it was acidified with acetic acid to $\mathrm{pH} \sim 5$, five-fold diluted with water; the precipitate was filtered off, washed with water, and dried. Yellow solid; yield: $65 \%$; mp $244{ }^{\circ} \mathrm{C} ;{ }^{1} \mathrm{H}$ NMR $\left(400 \mathrm{MHz}, \mathrm{CDCl}_{3}\right) \delta 2.51\left(\mathrm{~s}, 3 \mathrm{H}, \mathrm{CH}_{3}\right), 6.96(\mathrm{t}, J=7.3 \mathrm{~Hz}$, $1 \mathrm{H}, \mathrm{Py}), 7.28$ (t, $\left.J=7.4 \mathrm{~Hz}, J=7.7 \mathrm{~Hz}, 2 \mathrm{H}, \mathrm{C}_{6} \mathrm{H}_{5}\right), 7.45(\mathrm{~d}$, $\left.J=8.1 \mathrm{~Hz}, 3 \mathrm{H}, \mathrm{C}_{6} \mathrm{H}_{5}\right), 8.67(\mathrm{~s}, 1 \mathrm{H}, \mathrm{OH}) ;{ }^{13} \mathrm{C}$ NMR $(101$ $\left.\mathrm{MHz}, \mathrm{CDCl}_{3}\right) \delta 17.51,108.34,114.33,125.73,127.90$, $128.24,140.18,142.06,145.08,160.61,168.96$; ESI-MS: $\mathrm{m} / \mathrm{z} 258[\mathrm{M}+\mathrm{H}]^{+}$; anal. calcd. for $\mathrm{C}_{13} \mathrm{H}_{10} \mathrm{~N}_{2} \mathrm{O}_{2} \mathrm{~S}$ : C 60.45, $\mathrm{H}$ 3.90, N 10.85; found: C 60.06, H 3.84, N 10.73 . 
3-(5-Hydroxy-7-methyl-2-oxothiazolo[4,5-b]pyridin-3 $(2 \mathrm{H})$-yl) propanenitrile (5):

A mixture of pyridine $(50 \mathrm{~mL})$ and water $(10 \mathrm{ml})$ with acrylonitrile $(3 \mathrm{~mL})$ was added to the 5-hydroxy- 7-methylthiazolo[4,5- $b]$ pyridin-2(3H)-one $(1,10 \mathrm{mmol})$. The reaction mixture was refluxed for $5 \mathrm{~h}$. On cooling, the precipitation was achieved with petroleum ether-water mixture (3:1). The precipitate was recrystallized from ethanol, filtered off, and dried. This compound was isolated as a white crystalline solid, well soluble in ethanol, chloroform, dioxane, DMF, acetic acid. White solid; yield: $74 \%$; mp $105{ }^{\circ} \mathrm{C} ;{ }^{1} \mathrm{H}$ NMR $\left(400 \mathrm{MHz}, \mathrm{CDCl}_{3}\right) \delta 2.27\left(\mathrm{~s}, 3 \mathrm{H}, \mathrm{CH}_{3}\right), 3.04(\mathrm{t}, J=6.5 \mathrm{~Hz}$, $\left.2 \mathrm{H}, \mathrm{CH}_{2}\right), 4.15\left(\mathrm{t}, J=6.5 \mathrm{~Hz}, 2 \mathrm{H}, \mathrm{CH}_{2}\right), 6.41(\mathrm{~s}, 1 \mathrm{H}, \mathrm{Py}), 11.09$ (s, $1 \mathrm{H}, \mathrm{OH}) ;{ }^{13} \mathrm{C}$ NMR $\left(101 \mathrm{MHz}, \mathrm{CDCl}_{3}\right) \delta 15.77,19.15$, 37.48, 105.11, 105.80, 118.12, 144.70, 146.16, 162.53, 167.96; ESI-MS: $\mathrm{m} / \mathrm{z} 236[\mathrm{M}+\mathrm{H}]^{+}$; anal. calcd. for $\mathrm{C}_{10} \mathrm{H}_{9} \mathrm{~N}_{3} \mathrm{O}_{2} \mathrm{~S}$ : C 51.05, H 3.86, N 17.86; found: C 50.97, H 3.89, N 17.77.

\section{3-(5-Hydroxy-7-methyl-2-oxothiazolo[4,5-b]pyridin-3} $(2 \mathrm{H})-\mathrm{yl})$ propanoic acid (6):

The mixture of the propanenitrile $(5,10 \mathrm{mmol})$, acetic acid $(30 \mathrm{~mL})$, and hydrochloric acid $(15 \mathrm{~mL})$ were placed into the round-bottomed flask. The reaction mixture was refluxed $3 \mathrm{~h}$ and the product was precipitated with water. The mixture was left for $24 \mathrm{~h}$ at ambient temperature. The precipitate was filtered off and treated with toluene. The precipitate was recrystallized from ethanol, filtered off, and dried. This compound was isolated as a white crystalline powdered solid, well soluble in ethanol, chloroform, dioxane, DMF, acetic acid. White solid; yield: $66 \%$; mp $111^{\circ} \mathrm{C}$; ${ }^{1} \mathrm{H}$ NMR $\left(400 \mathrm{MHz}, \mathrm{CDCl}_{3}\right) \delta 2.25\left(\mathrm{~s}, 3 \mathrm{H}, \mathrm{CH}_{3}\right), 2.68(\mathrm{t}, J=$ $\left.7.5 \mathrm{~Hz}, 2 \mathrm{H}, \mathrm{CH}_{2}\right), 4.10\left(\mathrm{t}, J=7.6 \mathrm{~Hz}, 2 \mathrm{H}, \mathrm{CH}_{2}\right), 6.38(\mathrm{~s}, 1 \mathrm{H}$, Py), 11.05 (s, 1H, OH), 12.07 (s, $1 \mathrm{H}, \mathrm{COOH}) ;{ }^{13} \mathrm{C} \mathrm{NMR}$ $\left(101 \mathrm{MHz}, \mathrm{CDCl}_{3}\right) \delta 19.17,31.76,37.90,104.77,105.97$, 144.45, 146.62, 162.50, 167.85, 171.90; ESI-MS: m/z 254 $[\mathrm{M}+\mathrm{H}]^{+}$; anal. calcd. for $\mathrm{C}_{10} \mathrm{H}_{10} \mathrm{~N}_{2} \mathrm{O}_{4} \mathrm{~S}: \mathrm{C} 47.24, \mathrm{H} 3.96, \mathrm{~N}$ 11.02; found: C 47.88, H 3.98, N 11.21 .

General procedure for the synthesis of 3-(5-hydroxy7-methyl-2-oxothiazolo[4,5-b]pyridin-3(2H)-yl)-Naryl-1 propanamides $(7,8)$.

The mixture of the propanoic acid $(6,10 \mathrm{mmol})$, thionyl chloride $(57 \mathrm{mmol})$ and dioxane $(30 \mathrm{~mL})$ were placed into the round-bottomed flask. The reaction mixture was refluxed for $30 \mathrm{~min}$ and the product was precipitated with $\mathrm{n}$-hexane, the precipitate was filtered off. The resulting acyl chlorides were used for further transformations without further purification. Obtained 3-(5-hydroxy-7-methyl2-oxothiazolo[4,5-b]pyridin-3(2H)-yl)propanoyl chloride $(10 \mathrm{mmol})$ was dissolved in anhydrous dioxane $(10 \mathrm{~mL})$, and appropriate aromatic amine $(10 \mathrm{mmol})$ and triethylamine $(10 \mathrm{mmol})$ were added to the solution. The reaction mixture was refluxed for $15 \mathrm{~min}$. On cooling, the mixture was diluted with water and precipitated crystalline solid filtered off, washed with methanol and dried. The obtained compounds were recrystallized from acetic acid.
3-(5-Hydroxy-7-methyl-2-oxothiazolo[4,5-b]pyridin-3 (2H)-yl)-N-phenyl propanamide (7):

White solid; yield: $48 \%$; mp $214{ }^{\circ} \mathrm{C}$; ${ }^{1} \mathrm{H}$ NMR (400 $\left.\mathrm{MHz}, \mathrm{CDCl}_{3}\right) \delta 2.28\left(\mathrm{~s}, 3 \mathrm{H}, \mathrm{CH}_{3}\right), 2.71(\mathrm{t}, 2 \mathrm{H}, J=7.1 \mathrm{~Hz}$, $\left.\mathrm{CH}_{2}\right), 4.13\left(\mathrm{t}, 2 \mathrm{H}, J=7.2 \mathrm{~Hz}, \mathrm{CH}_{2}\right), 6.42(\mathrm{~s}, 1 \mathrm{H}, \mathrm{Py}), 7.21-$ $7.26\left(\mathrm{~m}, 2 \mathrm{H}, \mathrm{C}_{6} \mathrm{H}_{5}\right), 7.40-7.48\left(\mathrm{~m}, 3 \mathrm{H}, \mathrm{C}_{6} \mathrm{H}_{5}\right), 9.96(\mathrm{~s}, 1 \mathrm{H}$, $\mathrm{NH}), 11.09$ (s, $1 \mathrm{H}, \mathrm{OH}) ;{ }^{13} \mathrm{C}$ NMR $\left(101 \mathrm{MHz}, \mathrm{CDCl}_{3}\right) \delta$ $19.21,31.55,37.54,105.06,105.89,125.18,128.32,128.86$, $140.85,144.41,146.32,162.47,167.79,170.11$; ESI-MS: $\mathrm{m} / \mathrm{z} 329[\mathrm{M}+\mathrm{H}]^{+}$; anal. calcd. for $\mathrm{C}_{16} \mathrm{H}_{15} \mathrm{~N}_{3} \mathrm{O}_{3} \mathrm{~S}: \mathrm{C} 58.35, \mathrm{H}$ 4.59, N 12.76; found: C 58.43, H 4.67, N 12.88 .

3-(5-Hydroxy-7-methyl-2-oxothiazolo[4,5-b]pyridin-3 (2H)-yl)-N-(4-nitrophenyl) propan-amide (8):

Yellow solid; yield: $53 \%$; mp $202{ }^{\circ} \mathrm{C}$; ${ }^{1} \mathrm{H}$ NMR (400 $\left.\mathrm{MHz}, \mathrm{CDCl}_{3}\right) \delta 2.36\left(\mathrm{~s}, 3 \mathrm{H}, \mathrm{CH}_{3}\right), 2.85(\mathrm{t}, 2 \mathrm{H}, J=7.2 \mathrm{~Hz}$, $\left.\mathrm{CH}_{2}\right), 4.24\left(\mathrm{t}, 2 \mathrm{H}, J=7.2 \mathrm{~Hz}, \mathrm{CH}_{2}\right), 6.54(\mathrm{~s}, 1 \mathrm{H}, \mathrm{Py}), 7.35-$ $7.41\left(\mathrm{~m}, 2 \mathrm{H}, \mathrm{C}_{6} \mathrm{H}_{4}\right), 7.56-7.62\left(\mathrm{~m}, 2 \mathrm{H}, \mathrm{C}_{6} \mathrm{H}_{4}\right), 10.18(\mathrm{~s}, 1 \mathrm{H}$, $\mathrm{NH}), 11.14(\mathrm{~s}, 1 \mathrm{H}, \mathrm{OH}) ;{ }^{13} \mathrm{C}$ NMR $\left(101 \mathrm{MHz}, \mathrm{CDCl}_{3}\right) \delta$ $19.23,31.65,37.60,104.89,105.78,122.25,125.63,126.97$, 140.59, 144.24, 146.51, 162.51, 167.70, 170.24; ESI-MS: $\mathrm{m} / \mathrm{z} 375[\mathrm{M}+\mathrm{H}]^{+}$; anal. calcd. forC $\mathrm{C}_{16} \mathrm{H}_{14} \mathrm{~N}_{4} \mathrm{O}_{5} \mathrm{~S}: \mathrm{C} 51.33, \mathrm{H}$ 3.77, N 14.97; found: C 51.11, H 3.81, N 14.86.

\section{7-Methyl-2-oxo-2,3-dihydrothiazolo[4,5-b]pyridin-5-yl} 2-chloroacetate (9):

5-Hydroxy-7-methyl-thiazolo[4,5- $b$ ]pyridin-2(3H)one $(\mathbf{1}, 5 \mathrm{mmol})$, an appropriate aliphatic chloroacetyl chloride $(5 \mathrm{mmol})$, and triethylamine $(5 \mathrm{mmol})$ were added to dioxane $(20 \mathrm{~mL})$. The reaction mixture was refluxed $15 \mathrm{~min}$. On cooling, the formed crystalline precipitate was filtered off, washed with methanol and dried. The obtained compound was recrystallized from methanol. White solid; yield: $67 \%$; mp $191{ }^{\circ} \mathrm{C} ;{ }^{1} \mathrm{H}$ NMR $\left(400 \mathrm{MHz}, \mathrm{CDCl}_{3}\right) \delta 2.37(\mathrm{~s}, 3 \mathrm{H}$, $\left.\mathrm{CH}_{3}\right), 4.72-4.74\left(\mathrm{~m}, 2 \mathrm{H}, \mathrm{CH}_{2}\right), 6.92(\mathrm{~s}, 1 \mathrm{H}, \mathrm{Py}), 12.71(\mathrm{~s}$, $1 \mathrm{H}, \mathrm{NH}) ;{ }^{13} \mathrm{C} \mathrm{NMR}\left(101 \mathrm{MHz}, \mathrm{CDCl}_{3}\right) \delta 19.43,41.07$, $110.76,116.52,145.16,148.09,154.79,166.09,168.31$; ESIMS: $\mathrm{m} / \mathrm{z} 259[\mathrm{M}+\mathrm{H}]^{+}$; anal. calcd. for $\mathrm{C}_{9} \mathrm{H}_{7} \mathrm{ClN}_{2} \mathrm{O}_{3} \mathrm{~S}: \mathrm{C}$ 41.79, H 2.73, N 10.83; found: C 41.53, H 2.76, N 10.95.

General procedure for the synthesis of 7-methyl-2-oxo2,3-dihydrothiazolo[4,5-b]pyridin-5-yl 4-carboxylates (10-14).

To a solution of pyridine $(20 \mathrm{~mL})$ an appropriate aromatic acyl chloride $(5 \mathrm{mmol})$ and 5-hydroxy-7-methyl-thiazolo[4,5-b]pyridin-2(3H)-one $(1,5 \mathrm{mmol})$ were added. The reaction mixture was refluxed $30 \mathrm{~min}$. On cooling, formed crystalline precipitate was filtered off, washed with acetic acid and dried. The obtained compounds were recrystallized from acetic acid.

\section{7-Methyl-2-oxo-2,3-dihydrothiazolo[4,5-b]pyridin-5-yl 4-chlorobenzoate (10): \\ White solid; yield: $65 \%$; mp $214^{\circ} \mathrm{C} ;{ }^{1} \mathrm{H}$ NMR (400 $\left.\mathrm{MHz}, \mathrm{CDCl}_{3}\right) \delta 2.39\left(\mathrm{~s}, 3 \mathrm{H}, \mathrm{CH}_{3}\right), 7.06(\mathrm{~s}, 1 \mathrm{H}, \mathrm{Py}), 7.70(\mathrm{~d}$, $\left.J=8.5 \mathrm{~Hz}, 2 \mathrm{H}, \mathrm{C}_{6} \mathrm{H}_{4}\right), 8.13\left(\mathrm{~d}, J=8.5 \mathrm{~Hz}, 2 \mathrm{H}, \mathrm{C}_{6} \mathrm{H}_{4}\right), 12.74$}


(s, $1 \mathrm{H}, \mathrm{NH}) ;{ }^{13} \mathrm{C}$ NMR $\left(101 \mathrm{MHz}, \mathrm{CDCl}_{3}\right) \delta 19.45,111.25$, $116.31,127.14,129.32,131.67,139.41,145.08,148.15$, 155.32, 163.52, 168.35; ESI-MS: $\mathrm{m} / \mathrm{z} 320[\mathrm{M}+\mathrm{H}]^{+}$; anal. calcd. for $\mathrm{C}_{14} \mathrm{H}_{9} \mathrm{ClN}_{2} \mathrm{O}_{3} \mathrm{~S}: \mathrm{C} 52.42, \mathrm{H} 2.83, \mathrm{~N}$ 8.73; found: C 52.68, H 2.85, N 8.79.

\section{7-Methyl-2-oxo-2,3-dihydrothiazolo[4,5-b]pyridin-5-yl 4-(benzyloxy) benzoate (11):}

White solid; yield: $71 \%$; mp $197^{\circ} \mathrm{C} ;{ }^{1} \mathrm{H}$ NMR (400 $\left.\mathrm{MHz}, \mathrm{CDCl}_{3}\right) \delta 2.37\left(\mathrm{~s}, 3 \mathrm{H}, \mathrm{CH}_{3}\right), 7.01(\mathrm{~s}, 1 \mathrm{H}, \mathrm{Py}), 7.21$ (d, $\left.J=8.4 \mathrm{~Hz}, 2 \mathrm{H}, \mathrm{C}_{6} \mathrm{H}_{4}\right), 7.41\left(\mathrm{~d}, J=7.2 \mathrm{~Hz}, 2 \mathrm{H}, \mathrm{C}_{6} \mathrm{H}_{5}\right), 7.49$ $\left(\mathrm{d}, J=6.9 \mathrm{~Hz}, 3 \mathrm{H}, \mathrm{C}_{6} \mathrm{H}_{5}\right), 8.08\left(\mathrm{~d}, J=8.3 \mathrm{~Hz}, 2 \mathrm{H}, \mathrm{C}_{6} \mathrm{H}_{4}\right)$, 12.75 (s, $1 \mathrm{H}, \mathrm{NH}) ;{ }^{13} \mathrm{C}$ NMR $\left(101 \mathrm{MHz}, \mathrm{CDCl}_{3}\right) \delta 19.37$, $69.64,111.39,114.56,115.17,120.45,127.82,128.45$, $131.31,132.08,136.21,144.95,148.08,155.65,163.06$, 163.91, 168.47; ESI-MS: m/z $393[\mathrm{M}+\mathrm{H}]^{+}$; anal. calcd. for $\mathrm{C}_{21} \mathrm{H}_{16} \mathrm{~N}_{2} \mathrm{O}_{4} \mathrm{~S}$ : C 64.27, H 4.11, N 7.14; found: C 64.05, $\mathrm{H}$ $4.14, \mathrm{~N} 7.24$.

7-Methyl-2-oxo-2,3-dihydrothiazolo[4,5-b]pyridin-5yl-(E)-3-(4-methoxyphenyl) acrylate (12):

White solid; yield: $65 \%$; mp $169^{\circ} \mathrm{C} ;{ }^{1} \mathrm{H}$ NMR (400 $\left.\mathrm{MHz}, \mathrm{CDCl}_{3}\right) \delta 2.39\left(\mathrm{~s}, 3 \mathrm{H}, \mathrm{CH}_{3}\right), 3.79\left(\mathrm{~s}, 3 \mathrm{H}, \mathrm{CH}_{3}-\mathrm{C}_{6} \mathrm{H}_{4}\right)$, $6.37(\mathrm{~d}, 1 \mathrm{H}, J=16.0 \mathrm{~Hz}, \mathrm{CH}), 7.07(\mathrm{~s}, 1 \mathrm{H}, \mathrm{Py}), 6.97(\mathrm{~d}, J=$ $\left.8.7 \mathrm{~Hz}, 2 \mathrm{H}, \mathrm{C}_{6} \mathrm{H}_{4}\right), 7.55(\mathrm{~d}, 1 \mathrm{H}, 16.0 \mathrm{~Hz}, \mathrm{CH}), 7.63(\mathrm{~d}, J=$ $\left.8.7 \mathrm{~Hz}, 2 \mathrm{H}, \mathrm{C}_{6} \mathrm{H}_{4}\right), 12.17(\mathrm{~s}, 1 \mathrm{H}, \mathrm{NH}) ;{ }^{13} \mathrm{C}$ NMR $(101 \mathrm{MHz}$, $\left.\mathrm{CDCl}_{3}\right) \delta 19.64,55.12,105.11,106.80,114.29,116.45$, $126.77,129.87,143.69,145.55,146.82,158.53,160.88$, 167.79, 169.55; ESI-MS: $\mathrm{m} / \mathrm{z} 343[\mathrm{M}+\mathrm{H}]^{+}$; anal. calcd. for $\mathrm{C}_{17} \mathrm{H}_{14} \mathrm{~N}_{2} \mathrm{O}_{4} \mathrm{~S}$ : C 59.64, H 4.12, N 8.18; found: C 59.64, H 4.03, N 8.28.

7-Methyl-2-oxo-2,3-dihydrothiazolo[4,5-b]pyridin-5-yl 1-(3,4-dimethylphenyl)-5-methyl-1 H-1,2,3-triazole4-carboxylate (13):

White solid; yield: $77 \%$; mp $187^{\circ} \mathrm{C} ;{ }^{1} \mathrm{H}$ NMR (400 $\left.\mathrm{MHz}, \mathrm{CDCl}_{3}\right) \delta 1.99$ (s, 3H, $\mathrm{CH}_{3}$-triazole), 2.38 (s, 3H, $\left.\mathrm{CH}_{3}\right), 2.40$ (s, $\left.3 \mathrm{H}, \mathrm{CH}_{3}-\mathrm{C}_{6} \mathrm{H}_{3}\right), 2.41\left(\mathrm{~s}, 3 \mathrm{H}, \mathrm{CH}_{3}-\mathrm{C}_{6} \mathrm{H}_{3}\right)$, 7.08 (s, $1 \mathrm{H}, \mathrm{Py}), 7.28\left(\mathrm{~d}, J=8.0 \mathrm{~Hz}, 1 \mathrm{H}, \mathrm{C}_{6} \mathrm{H}_{3}\right), 7.36-7.38$ $\left(\mathrm{m}, 2 \mathrm{H}, \mathrm{C}_{6} \mathrm{H}_{3}\right), 12.78(\mathrm{~s}, 1 \mathrm{H}, \mathrm{NH}) ;{ }^{13} \mathrm{C}$ NMR $(101 \mathrm{MHz}$, $\left.\mathrm{CDCl}_{3}\right) \delta 9.34,16.61,19.46,20.74,111.26,116.31,127.08$, $127.68,131.33,131.82,134.14,134.67,140.78,141.62$, 145.08, 148.21, 154.98, 159.20, 168.37; ESI-MS: m/z 398 $[\mathrm{M}+\mathrm{H}]^{+}$; anal. calcd. for $\mathrm{C}_{19} \mathrm{H}_{17} \mathrm{~N}_{5} \mathrm{O}_{3} \mathrm{~S}$ : C $57.71, \mathrm{H} 4.33, \mathrm{~N}$ 17.71; found: C 57.59, H 4.28, N 17.82.

7-Methyl-2-oxo-2,3-dihydrothiazolo[4,5-b]pyridin-5-yl 1-(2-chlorophenyl)-5-methyl-1H-1,2,3-triazole-4-carboxylate (14):

White solid; yield: $64 \%$; mp $178^{\circ} \mathrm{C} ;{ }^{1} \mathrm{H}$ NMR (400 $\left.\mathrm{MHz}, \mathrm{CDCl}_{3}\right) \delta 2.01$ (s, 3H, $\mathrm{CH}_{3}$-triazole), $2.37(\mathrm{~s}, 3 \mathrm{H}$, $\left.\mathrm{CH}_{3}\right), 7.01(\mathrm{~s}, 1 \mathrm{H}, \mathrm{Py}), 6.94-6.98\left(\mathrm{~m}, 1 \mathrm{H}, \mathrm{C}_{6} \mathrm{H}_{4}\right), 7.40-7.45$ $\left(\mathrm{m}, 1 \mathrm{H}, \mathrm{C}_{6} \mathrm{H}_{4}\right), 7.53-7.58\left(\mathrm{~m}, 2 \mathrm{H}, \mathrm{C}_{6} \mathrm{H}_{4}\right), 12.78(\mathrm{~s}, 1 \mathrm{H}$, $\mathrm{NH}) ;{ }^{13} \mathrm{C}$ NMR $\left(101 \mathrm{MHz}, \mathrm{CDCl}_{3}\right) \delta 19.39,20.70,104.18$, $111.03,116.02,144.05,144.69,144.71,147.50 .148 .31$, $148.33,148.38,155.32,162.36,168.44,168.88$ 168.11;
ESI-MS: $\mathrm{m} / \mathrm{z} 403[\mathrm{M}+\mathrm{H}]^{+}$; anal. calcd. for $\mathrm{C}_{17} \mathrm{H}_{12} \mathrm{Cl}-$ $\mathrm{N}_{5} \mathrm{O}_{3} \mathrm{~S}$ : C 50.81, H 3.01, N 17.43; found: C 51.07, H 3.06, $\mathrm{N} 17.51$.

\section{3. Molecular Docking}

Molecular docking was conducted with OpenEye Scientific Software program package as a computer method approach to the search of molecules with affinity to certain biotargets. Used software includes Fred Receptor, Vida, Flipper, Babel 3, Omega 2 and Fred 2 programs.

\section{4. Anti-inflammatory Activity Evaluation Assays}

Anti-inflammatory activity ${ }^{39}$ was evaluated using carrageenan induced rat paw edema method in rats. Outbred (male/female) white rats weighing 180-220g were used for the edema test. The experiments were carried out in accordance with the requirements of the European convention for the protection of vertebrate animals used for experimental and other scientific purposes. The experimental protocol was approved by the Danylo Halytsky Lviv National Medical University ethics committee, constituted by the Ministry of Health of Ukraine.

Animals were divided into 15 groups comprising five rats per group. One group was kept as the control and remaining 14 groups (test groups) were used to determine the anti-inflammatory activity elicited by the 13 drug candidates, respectively. Rats were kept in the animal house under standard conditions of light and temperature on the general diet prior to the experiment. The standard drug, Ibuprofen ( $50 \mathrm{mg} / \mathrm{kg}$ body weight) and the test compounds (50 $\mathrm{mg} / \mathrm{kg}$ body weight) were dissolved in DMSO and administered through intraperitoneal route. DMSO was injected to the control group. At 30 minutes later, $0.1 \mathrm{ml}$ of 2 $\%$ carrageenan solution in saline was injected in the sub-plantar region of the right hind paw of each rat. After $4 \mathrm{~h}$ of the carrageenan injection, the volume of paw edema (in $\mathrm{ml}$ ) was measured using water plethysmometer and decrease in paw edema was compared between the control group and the test groups. The inflammatory reaction inhibition was expressed as a percent of paw volume reduction and it was calculated using the following formula:

$$
\% \text { Inhibition }=\frac{V_{\text {control }}-V}{V_{\text {control }}} \cdot 100 \%
$$

where $V_{\text {control }}$ is the increase in paw volume in control group animals, and $V$ is the increase in paw volume in animals injected with the test substances.

\section{5. Antioxidant Activity Evaluation Assays}

The antioxidant activity was determined on the basis of free radical scavenging activity of stable 2,2-diphe- 
nyl-1-picrylhydrazyl (DPPH). The effect of the studied compounds on DPPH radicals was estimated according to the method of Blois ${ }^{40-41}$ with minor modifications. The solution of DPPH in ethanol with the concentration of 150 $\mu$ moles/L $(4 \mathrm{~mL})$ was mixed with the compound or control solution in ethanol its concentration been $250 \mu$ moles/L $(0.2 \mathrm{~mL})$. The reaction mixture was vortex mixed thoroughly and incubated at room temperature in the dark for $60 \mathrm{~min}$. Simultaneously, a control was prepared as ascorbic acid solution in ethanol $(0.2 \mathrm{~mL})$ mixed with of DPPH solution in ethanol $(4 \mathrm{~mL})$ without sample fraction. Reduction in the absorbance of the mixture was measured at $517 \mathrm{~nm}$ using ethanol as blank. Ascorbic acid was used as a standard. Also, the absorbance of DPPH solution was measured. Percentage of free-radical-scavenging activity was expressed as percent inhibition and it was calculated using the following formula:

$$
\% \text { Inhibition }=\frac{\grave{\mathrm{A}}_{\mathrm{DPPH}}-\mathrm{A}_{\mathrm{c}}}{\mathrm{A}_{\mathrm{DPPH}}} \cdot 100 \% \text {; }
$$

where $A_{D P P H}$ is the absorbance of DPPH free radicals solution, and $A_{c}$ is the absorbance of a sample. Each experiment was performed in triplicate and average values were recorded. Results are expressed as the means \pm S.D.

\section{Results and Discussion}

\section{1. Chemistry}

Continuing systematic study of fused bicyclic systems as potential drug candidates we represented synthesis, anti-inflammatory and antioxidant activity evaluation of some thiazolo[ $[4,5-b]$ pyridin-2-ones. The efficient synthetic approach for $3 H$-thiazolo[4,5-b]pyridin-2-one $e^{23,36}$ system construction had been developed earlier and is based on [3+3] cyclocondensation of 4-iminothiazolidone-2 due its N,C-binucleophilic properties with dielectrophilic reagents like ethyl acetoacetate forming the above-mentioned fused heterocycle (1). ${ }^{33}$

We studied the behavior of 4-iminothiazolidin-2-one with $\alpha$-arylazo- derivatives of ethyl acetoacetate in $[3+3]$ cyclocondensation reaction. Under the chosen conditions the corresponding 6-arylazo-5-hydroxy-7-methyl-3H-thiazolo[4,5-b]pyridin-2-ones $(2,3)$ were obtained in good yields (Scheme).

We looked at a possibility to use the reported method for preparation of 3-phenyl-5-hydroxy-7-methyl-3 $\mathrm{H}$ thiazolo[4,5-b]pyridin-2-one (4) from above mentioned ethyl acetoacetate and 3-phenyl-4-iminothiazolidone2-one. It was found that compound $\mathbf{4}$ was easily accessed with a high yield at the same conditions (Scheme).<smiles>[Y]NC(=O)CCn1c(=O)sc2c(C)cc(O)nc21</smiles>

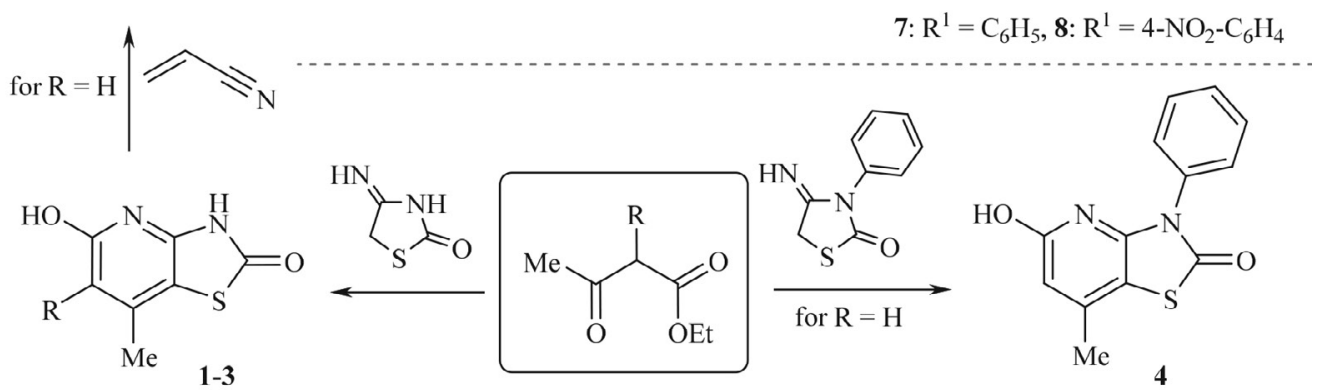
$1-3$

1: $\mathrm{R}=\mathrm{H} ; 2: \mathrm{R}=\mathrm{N}=\mathrm{N}-4-\mathrm{SO}_{3} \mathrm{H}-\mathrm{C}_{6} \mathrm{H}_{4} ; 3: \mathrm{R}=\mathrm{N}=\mathrm{N}-2$-naphthalen

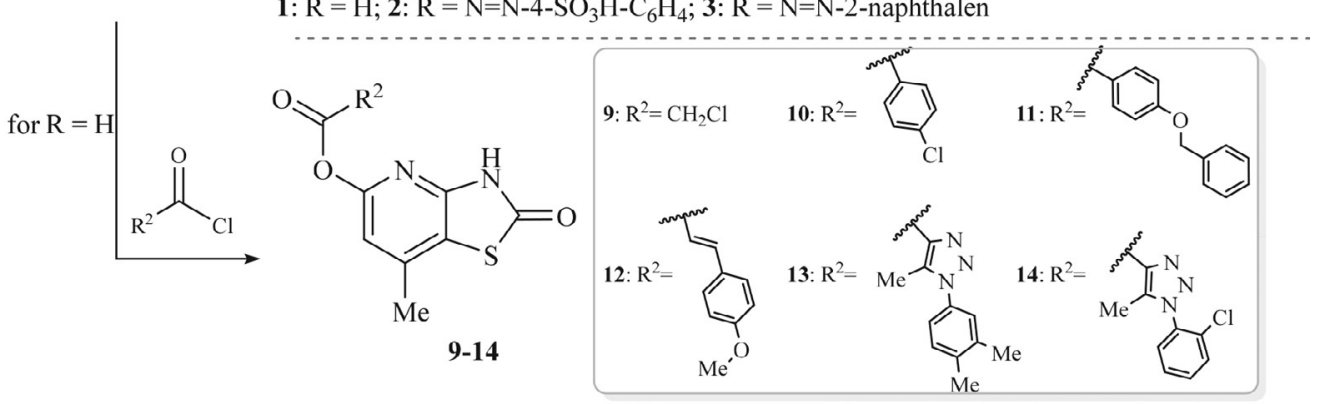

Scheme 1. Synthesis of novel thiazolo[4,5- $b]$ pyridine derivatives. 
The further strategy included the core heterocycle structural modification at its $\mathrm{N}^{3}$ position. Core thiazolo[4,5- $b]$ pyridine scaffold had been extensively studied as electrophilic reagent due the presence of $\mathrm{NH}$-group hydrogen atom. Therefore, the functionalization of thiazolo $[4,5-b]$ pyridine could be easily performed via the addition reaction to the acrylonitrile. We have found out that the high yield of the product 5 could be achieved while treatment of the equimolar amounts of the thiazolo[4,5- $b]$ pyridine (1) with acrylonitrile in pyridine water medium (5:1). 3-(5-Hydroxy-7-methyl-2-oxothiazolo[4,5-b]pyridin-3(2H)-yl) propanenitrile (5) prepared in this way was subjected to hydrolysis leading to 3-(5-hydroxy-7-methyl-2-oxothiazolo[4,5-b]pyridin-3(2H)-yl) propanoic acid (6) formation (Scheme).

Besides, propanamides are highly reactive substances, hence suitable for creating and broadening the collection of building blocks useful for combinatorial chemistry including the design of biologically active compounds. The carboxyl group present in $\mathrm{N}^{3}$ position of thiazolo[4,5-b] pyridinyl-propanoic acid (6) provides an entry to 3-(5-hydroxy-7-methyl-2-oxothiazolo[4,5-b]pyridin-3(2H)-yl)-N-aryl propanamides $(7,8)$. Dioxane was established to be the most suitable medium for the reaction of compound 6 with thionyl chloride. Prepared in this way, 3-(5-hydroxy-7-methyl-2-oxothiazolo[4,5-b]pyridin-3(2H)-yl) propanoyl chloride was reacted with corresponding aromatic amines. Refluxing the reaction mixture for $30 \mathrm{~min}$ in dioxane medium was defined as optimal condition for propanamides $(7,8)$ formation in good yields (Scheme).

Furthermore, compound 1, due to the presence of hydroxyl- moiety in position 5 of thiazolo[4,5-b]pyridine core, represents a convenient reagent for thiazolo[4,5- $b$ ] pyridin-5-yl 4-carboxylates (9-14) generation via acylation reaction by chloroacetyl chloride or appropriate aromatic acyl chlorides (Scheme). Powders of these products are well soluble in DMF, DMSO and acetic acid, and sparingly soluble in water and in other organic solvents.
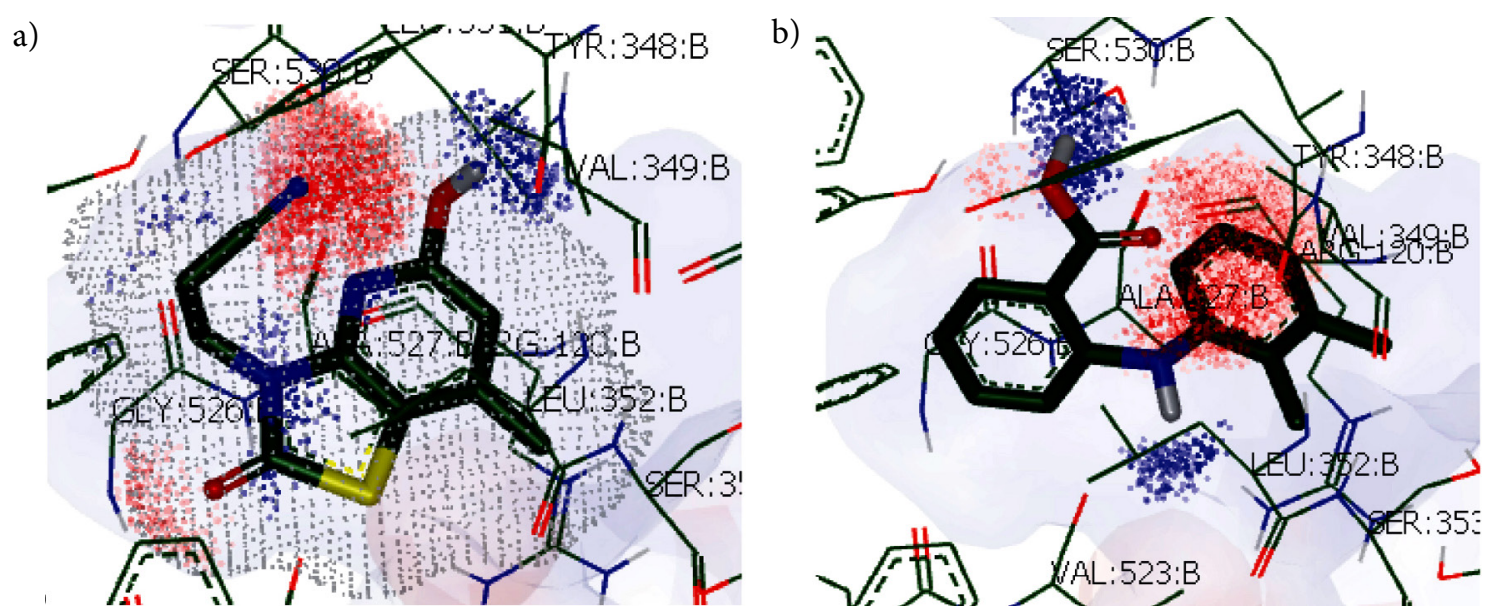

Figure 1. Compound 5 docked in the active site of COX-2 (a) in comparison with inhibitor mefenamic acid docked in the active site of COX2. (b).

Chaban et al.: Synthesis, Molecular Docking and Biological ... 
Values of the seven scoring functions (Chemgauss 2, Chemscore, PLP, Screenscore, Shapegauss, Zapbind and Consensus) were obtained as a result. Ranking property (compound ranking) of the consensus scoring function, which includes values of all scoring functions, allowed to analyze the results easily.

Ranking and analysis of the molecular docking results were obtained using the selected compounds and crystallographic model of COX-2 with cumulative scoring function (consensus). Consensus results allowed us to select compounds, which could prospectively be selective COX-2 inhibitors at the level of mefenamic acid and Ibuprofen for future (in-depth) pharmacological studies for further evaluation of in vitro anti-inflammatory activity. The interactions between COX-2 active site and the most active compound $\mathbf{5}$ in comparison with selective inhibitor mefenamic acid is shown in Figure. Moreover, it should be noted that results predicted via docking correlate quite well with that obtained in the in vitro assay. The selected "lead" compound 5 based on the in vitro screening results was also predicted to be the most active in the docking studies.

On the contrast, generated conformations of thiazolo[4,5- $b]$ pyridine derivatives did not possess the necessary parameters for successful binding to the target COX-1 active site and were found to be bad substrates of cyclooxygenase-1 during docking experiment.

\section{3. Anti-inflammatory Activity in Vivo Evaluation}

Carrageenan-induced paw edema is the most widely used animal model of acute inflammation. In vivo studies of novel thiazolo[4,5- $b$ ]pyridine-2-one derivatives were carried out for anti-inflammatory activity employing the carrageenan-induced rat paw edema method. The NSAID drug Ibuprofen in its effective therapeutic dose was tested in parallel as an activity reference. Results of paw edema decreasing were expressed as the mean \pm standard deviation and compared statistically with the control group using Student's t-test. A level of $p<0.05$ was adopted as the test of significance (Table 1). The percentage protection against inflammation was calculated as \% inhibition by comparison between DMSO injected control group and drugs-tested groups.

Evaluation of anti-inflammatory activity indicated that 8 compounds $(2,3,7,8,10,11,12$ and 13$)$ showed no significant decrease in edema; the inhibition rate for them was observed at the level of $22.6-30.1 \%$ as compared to control group. The compounds 4,9 and 14 possessed the anti-inflammatory activity in the range of $35.6-42.1 \%$ which is comparable to the effect of Ibuprofen. The anti-inflammatory evaluation test for compounds $\mathbf{5}$ and $\mathbf{6}$ gave the result at the level of 45.3-48.8 \% inhibition indicating that the compounds $\mathbf{5}$ and $\mathbf{6}$ were more potent than Ibuprofen.

The results of the pharmacological tests were analyzed concerning the structure of the compounds. Among the two arylazo substituted derivatives 2-3 none of them was defined as active indicating the nature and position of the substituted arylazo groups did not noticably influence on their anti-inflammatory activity. It was found out that for $\mathrm{N}^{3}$-substituted 5-hydroxy-7-methyl-3H-thiazolo [4,5b]pyridin-2-one derivative (4), obtained via [3+3]cyclocondensation 3-phenyl-4-iminothiazolidone-2-one with ethyl acetoacetate, the presence of phenyl goup in the $\mathrm{N}^{3}$ position contributed to the inflammation inhibition efficiency. The presence of cyano and carboxy groups substituents $(5,6)$ in the core scaffold $\mathrm{N}^{3}$ position lead to the high anti-inflammatory activity even exceeding the Ibuprofen

Table 1. Anti-inflammatory effect of thiazolo $[4,5-b]$ pyridine-2-ones on carrageenan-induced rat paw edema $(\mathrm{ml})$ in vivo evaluation and $\%$ of protection from inflammation

\begin{tabular}{cccc}
\hline compound ID & $\begin{array}{c}\text { paw edema volume } \\
(\mathbf{m L}) \pm \text { SEM }^{\star}\end{array}$ & inhibition, \% & $\begin{array}{c}\text { activity relative to } \\
\text { Ibuprofen, \% }\end{array}$ \\
\hline control & $2.20 \pm 0.050$ & - & - \\
$\mathbf{2}$ & $1.62 \pm 0.035$ & 26.3 & 65.4 \\
$\mathbf{3}$ & $1.60 \pm 0.035$ & 27.5 & 68.4 \\
$\mathbf{4}$ & $1.27 \pm 0.020$ & 42.1 & 104.7 \\
$\mathbf{5}$ & $1.13 \pm 0.020$ & 48.8 & 121.4 \\
$\mathbf{6}$ & $1.20 \pm 0.020$ & 45.3 & 112.7 \\
$\mathbf{7}$ & $1.65 \pm 0.040$ & 25.2 & 62.7 \\
$\mathbf{8}$ & $1.68 \pm 0.040$ & 23.7 & 59.0 \\
$\mathbf{9}$ & $1.42 \pm 0.030$ & 35.6 & 88.6 \\
$\mathbf{1 0}$ & $1.54 \pm 0.030$ & 30.1 & 74.9 \\
$\mathbf{1 1}$ & $1.64 \pm 0.040$ & 25.5 & 63.4 \\
$\mathbf{1 2}$ & $1.70 \pm 0.040$ & 22.6 & 56.2 \\
$\mathbf{1 3}$ & $1.62 \pm 0.035$ & 26.3 & 65.4 \\
$\mathbf{1 4}$ & $1.41 \pm 0.030$ & 36.1 & 89.8 \\
Ibuprofen & $1.32 \pm 0.035$ & 40.2 & 100 \\
\hline
\end{tabular}

Chaban et al.: Synthesis, Molecular Docking and Biological ... 
effect. Notably, among the six $\mathrm{C}^{5}$-substituted 5-hydroxy-7methyl-3H-thiazolo[ $4,5-b]$ pyridin-2-one derivatives, prepared by the acylation reaction, only two compounds: chloro-acetic acid (9) and 1-(2-chloro-phenyl)-5-methyl$1 H$-[1,2,3]triazole-4-carboxylic acid (14) possessed inflammation inhibition. The rest of substituents in the $\mathrm{C}^{5}$ position did not notably affect on the anti-inflammatory activity of thiazolo[4,5- $b]$ pyridin-2-ones.

\section{4. In Vitro Antioxidant Assay}

The antioxidant activity was determined on the basis of free radical scavenging activity of 2,2-diphenyl-1-picrylhydrazyl (DPPH) free radical. The DPPH method is described as a simple, rapid and convenient method for screening of many samples for radical scavenging activity. These advantages make the DPPH method interesting for testing newly synthesized compounds to scavenge radicals and to find out antioxidant drug candidates.

DPPH radical had found many applications due to its high stability in a methanolic solution and intense purple color. In its oxidized form, the DPPH radical has an absorbance maximum at a wavelength of $540 \mathrm{~nm}$. The absorbance decreases when the radical is reduced by antioxidants. Its reduction affords 2,2-diphenyl-1-picrylhydrazine (DPPH-H), or the corresponding anion $\left(\mathrm{DPPH}^{-}\right)$in basic medium. The DPPH radical acts as a scavenger for other odd-electron species which afford para-substitution products at phenyl rings. In the present paper, we demonstrate modified spectrophotometric method making use of the DPPH radical and its specific absorbance properties. The free-radical-scavenging activity of each compound was assayed using a stable DPPH and was quantified by decolorization the solution being mixed with DHHP at a wavelength of $540 \mathrm{~nm}$. The absorbance of DPPH solution in ethanol (150 mmoles/l) was measured as 0.77 . The ab-

Table 2. Values of Absorbance and \% of inhibition of thiazolo[4,5- $b$ ] pyridine-2-ones.

\begin{tabular}{ccr}
\hline $\begin{array}{c}\text { compound / } \\
\text { standard }\end{array}$ & $\begin{array}{c}\text { Absorbance } \\
\text { of a sample, } \mathbf{A}_{\mathbf{s}}\end{array}$ & $\begin{array}{c}\text { inhibition, } \\
\text { \% }\end{array}$ \\
\hline $\begin{array}{c}\text { ascorbic acid } \\
\mathbf{2}\end{array}$ & $0.220 \pm 0.010$ & 71.5 \\
$\mathbf{3}$ & $0.718 \pm 0.025$ & 6.7 \\
$\mathbf{4}$ & $0.700 \pm 0.025$ & 9.1 \\
$\mathbf{5}$ & $0.671 \pm 0.020$ & 12.8 \\
$\mathbf{6}$ & $0.742 \pm 0.025$ & 3.7 \\
$\mathbf{7}$ & $0.759 \pm 0.030$ & 1.5 \\
$\mathbf{8}$ & $0.525 \pm 0.015$ & 31.8 \\
$\mathbf{9}$ & $0.549 \pm 0.015$ & 28.7 \\
$\mathbf{1 0}$ & $0.559 \pm 0.020$ & 27.4 \\
$\mathbf{1 1}$ & $0.546 \pm 0.015$ & 29.1 \\
$\mathbf{1 2}$ & $0.745 \pm 0.030$ & 3.3 \\
$\mathbf{1 3}$ & $0.523 \pm 0.015$ & 32.0 \\
$\mathbf{1 4}$ & $0.702 \pm 0.025$ & 8.8 \\
\hline
\end{tabular}

sorbances and free-radical-scavenging activities \% inhibitions of standard (ascorbic acid) and each compound are listed in Table 2.

The antioxidant activity evaluation results showed that, in general, most of the tested compounds possess insignificant free radical scavenging effect being in the range of $1.5 \%-32.0 \%$.

\section{Conclusions}

In summary, we presented an efficient synthetic approaches to a number of thiazolo $[4,5-b]$ pyridin-2-one derivatives for their anti-inflammatory and antioxidant activity evaluation. We have shown that the proposed synthetic protocols provided the possibility to design 5-hydroxy-7-methyl-3H-thiazolo[4,5- $b]$ pyridin-2-ones diversity with a considerable chemical novelty involving $[3+3]$ cyclocondensation, cyanoethylation, hydrolysis, and acylation reactions. The obtained results of the performed biological activity evaluation suggested the core fused heterocycle as a promising scaffold in anti-inflammatory drug development. On the contrary, the free radical scavenging effect was found to be insignificant. Further optimization of the structure to improve biological activity is currently in progress.

\section{References}

1. P. Pirlamarla, R. M. Bond, Trends Cardiovasc. Med. 2016, 26, 675-680. DOI:10.1016/j.tcm.2016.04.011

2. M. J. Killeen, M. Linder, P. Pontoniere, R. Crea, Drug Discovery Today 2014, 19, 373-378. DOI:10.1016/j.drudis.2013.11.002

3. S. Bacchi, P. Palumbo, A. Sponta, M. Coppolino, Anti-Inflamm. Anti-Allergy Agents Med. Chem. 2012, 11, 52-64. DOI: $10.2174 / 187152312803476255$

4. A. M. Qandil, Int. J. Mol. Sci. 2012, 13, 17244-17274. DOI:10.3390/ijms131217244

5. O. Kolomoets, O. Voskoboynik, O. Antypenko, G. Berest, I. Nosulenko, V. Palchikov, O. Karpenko, S. Kovalenko, Acta Chim. Slov. 2017, 64, 902-910. DOI:10.17344/acsi.2017.3575

6. T. Chaban, V. Matiychuk, V. Ogurtsov, I. Chaban, S. Harkov, I. Nektegaev, Pharmacia 2019, 65, 51-62.

7. R. Paprocka, M. Wiese, A. Eljaszewicz, A. Helmin-Basa, A. Gzella, B. Modzelewska-Banachiewicz, J. Michalkiewicz, Bioorg. Med. Chem. Lett. 2015, 25, 2664-2667.

DOI:10.1016/j.bmcl.2015.04.079

8. N. Smirnoff, New Phytol. 1993, 125, 27-58. DOI:10.1111/j.1469-8137.1993.tb03863.x

9. A. A. Arora, R. K. Sairam, G. C. Srivastava, Curr. Sci. 2002, 82, 1227-1238. DOI:10.4236/as.2015.68082

10. R. A. Jacob, B. J. Burri, Am. J. Clin. Nutr. 1996, 63, 985-990. DOI:10.1093/ajcn/63.6.985

11. H. Sies, W. Stahl, Am. J. Clin. Nutr. 1995, 62, 1315-1321. DOI:10.1093/ajcn/62.6.1315S 
12. Z. Chaban, S. Harkov, T. Chaban, O. Klenina, V. Ogurtsov, I. Chaban, Pharmacia 2017, 64, 52-66.

13. N. G. Smirnova, I. V. Zavarzin, M. M. Krayushkin, Chem. Heterocycl. Compd. 2006, 42, 144-165. DOI:10.1007/s10593-006-0064-8

14. T. Chaban, O. Klenina, I. Chaban, V. Ogurtsov, S. Harkov, M. Lelyukh, Pharmacia 2018, 65, 54-70.

15. Yu. I. Gorak, N. D. Obushak, V. S. Matiichuk, R. Z. Lytvyn, Russ. J. Org. Chem. 2009, 45, 541-550.

DOI:10.1134/S1070428009040125

16. N. T. Pokhodylo, R. D. Savka, V. S. Matiichuk, N. D. Obushak, Russ. J. Org. Chem. 2009, 79, 309-314. DOI: $10.1134 /$ S1070363209020248

17. V. S. Matiichuk, M. A. Potopnyk, N. D. Obushak, Russ. J. Org. Chem. 2008, 44, 1352-1361. DOI:10.1134/S1070428008090182

18. N. D. Obushak, Yu. I. Gorak, V. S. Matiichuk, R. Z. Lytvyn, Russ. J. Org. Chem. 2008, 44, 1689-1694.

DOI:10.1134/S1070428008110213

19. V. S. Sokolova, E. A. Khrustalev, V. N. Varlamov, M. D.Obushak, V. S.Matiychuk, E. A. Sokolova, V. N. Khrustalev, Tetrahedron Lett. 2010, 51, 6822-6824.

DOI:10.1016/j.tetlet.2010.10.046

20. N. Zelisko, D. Atamanyuk, Y. Ostapiuk, A. Bryhas, V. Matiychuk, A. Gzella, R. Lesyk, Tetrahedron. 2015, 71, 9501-9508. DOI:10.1016/j.tet.2015.10.019

21. N. T. Pokhodylo, O. Ya. Shyyka, N. D. Obushak, Chem. Heterocycl. Compd. 2015, 50, 1748-1755.

DOI:10.1007/s10593-015-1647-z

22. N. T. Pokhodylo, O. Ya. Shyyka, N. D. Obushak, Chem. Heterocycl. Compd. 2018, 54, 773-779.

DOI:10.1007/s10593-018-2348-1

23. T. I. Chaban, B. S. Zimenkovskii, J. D. Komaritsa, I. G. Chaban, Russ. J. Org. Chem. 2012, 48, 268-272.

DOI:10.1134/S1070428012020170

24. S. G. Hegde, M. D. Mahoney, J. Agric. Food Chem. 1993, 41, 2131-2134. DOI:10.1021/jf00035a058

25. O. Klenina, I. Drapak, T. Chaban, V. Ogurtsov, I. Chaban, I. Golos, Chem. Chem. Technol. 2013, 7, 397-404.

26. T. I. Chaban, V. V. Ogurtsov, I. G. Chaban, O. V. Klenina, J. D. Komarytsia, Phosphorus, Sulfur Silicon Relat. Elem. 2013, 188, 1611-1620. DOI:10.1080/10426507.2013.777723
27. O. V. Klenina, T. I. Chaban, B. Zimenkovsky, S. Harkov, V. V. Ogurtsov, I. Chaban, I. Myrko, Pharmacia 2017, 64, 49-71.

28. T. Chaban, V. Ogurtsov, A. Mahlovanyy, N. Sukhodolska, I. Chaban, S. Harkov, V. Matiychuk, Pharmacia 2019, 66, 171180. DOI:10.3897/pharmacia.66.e36764

29. H. H. Saeyd, E. M. Morsy, E. R. Kotb, Sci. Commun. 2010, 40, 2712-2722. DOI:10.1080/00397910903318674

30. S. Marzoog, Al-Thebeiti, Il Farmaco 2000, 55, 109-118. DOI:10.1016/S0014-827X(99)00130-5

31. V. Victor, B. Semenov, V. A. Lichitsky, N. A. Komogortsev, A. M. Dudinov, M. M. Krayushkin, Eur. J. Med. Chem. 2017, 125, 573-585. DOI:10.1016/j.ejmech.2016.09.075

32. Y. R. Lee, S. S. Yoo, Bull. Korean Chem. Soc. 2008, 1, 234-236.

33. T. Chaban, O. Klenina, I. Drapak, V. Ogurtsov, I. Chaban,V. Novikov, Chem. Chem. Technol. 2014, 89, 287-292.

34. T. Chaban, O. Klenina, B. Zimenkovsky, I. Chaban,V. Ogurtsov, L.Shelepeten. Der Pharma Chem. 2016, 8, 534-542.

35. T. Chaban, O. Klenina, S. Harkov, V. Ogurtsov, I. Chaban, I. Nektegaev, Pharmacia. 2017, 64, 16-30.

36. T. I. Chaban, V. V. Ogurtsov, V. S. Matiychuk, I. G. Chaban, I. L. Demchuk, I. A. Nektegayev, Acta Chim. Slov. 2019, 66, 103-111. DOI:10.17344/acsi.2018.4570

37. T. I. Chaban, R. R. Panchuk, O. V. Klenina, N. R. Skorokhyd, V. V. Ogurtsov, I. G. Chaban, Biopolymers \&Cell. 2012, 25, 389-396. DOI:10.7124/bc.000075

38. A. U. Rao, A. Palani, X. Chen, Y. Huang, R. G. Aslanian, R. E. West, Jr. Shirley, M. Williams, R-L. Wu, J. Hwa, C. Sondey, J. Lachowicz, Bioorg. Med. Chem. Lett. 2009, 19, 6176-6180. DOI: $10.1021 / \mathrm{ml} 200250 \mathrm{t}$

39. A. D. Pillai, P. D. Rathod, P. X. Franklin, H. Padh, K. K. Vasu, V. Sudarsanam, Biochem. Biophys. Res. Commun. 2004, 317, 1067-1074. DOI:10.1016/j.bbrc.2004.03.148

40. M. S. Blois, Nature. 1958, 181, 1199-1200.

DOI:10.1038/1811199a0

41. P. Molyneux, J. Sci. Technol. 2004, 26, 211-219.

DOI:10.1136/inpract.26.4.226

42. O. Shyyka, N. Pokhodylo, N. Finiuk, V. Matiychuk, R. Stoika, M. Obushak, Sci. Pharm. 2018, 86, E28.

DOI: $10.3390 /$ scipharm 86030028

43. N. T. Pokhodylo, O. Ya. Shyyka, V. S. Matiychuk, Med. Chem. Res. 2014, 23, 2426-2438. DOI:10.1007/s00044-013-0841-8

\section{Povzetek}

V prispevku je predstavljena sinteza ter protivnetne in antioksidativne lastnosti novih derivatov 5-hidroksi-7-metil-3Htiazolo[4,5-b]piridin-2-ona. Kondenzirani tiazolo[4,5-b]piridin-2-oni so bili sintetizirani in modificirani na položajih $\mathrm{N}^{3}, \mathrm{C}^{5}$ in $\mathrm{C}^{6}$ glavnega obroča in s tem dobili spojine z zadovoljivim farmakološkim profilom. Sintetizirane spojine so bile predhodno izbrane s pomočjo molekulskega modeliranja za nadaljnje testiranje njihove protivnetne aktivnosti in vitro. Vrednotenje novih spojin pri edemu podganjih tačk, ki ga povzroča karagenin, je pokazalo močno protivnetno delovanje nekaterih spojin, vključno s (tiazolo [4,5-b] piridin-3(2H)-il) propanenitrilom (5) in tiazolo[4,5-b]piridin-3(2H)-il) propanojsko kislino (6), ki celo presegata standard - Ibuprofen. Antioksidativno aktivnost sintetiziranih spojin so izmerili in vitro $\mathrm{z}$ metodo lovljenja na 2,2-difenil-1-pikrilhidrazil (DPPH) radikalih.

Except when otherwise noted, articles in this journal are published under the terms and conditions of the Creative Commons Attribution 4.0 International License 